\title{
THE HUMAN RIGHTS PROTECTION IN THE ECONOMIC AFFAIRS OF INDONESIA
}

\author{
Siti Rodhiyah Dwi Istinah \\ Sultan Agung Islamic University \\ rodhiyah@unissula.ac.id \\ Sri Kusriyah \\ Sultan Agung Islamic University \\ kusriyah@unissula.ac.id \\ Rakhmat Bowo Suharto \\ Sultan Agung Islamic University \\ rakhmat@unissula.ac.id
}

\begin{abstract}
The purpose of this study is to analyze and explain the protection of human rights in the economic sector for citizens to be able to enjoy a socially just economic development as well as to analyze and explain the challenges and obstacles in protecting human rights in the economic sector in an effort to realize social justice in the Constitution 1945. important in the constitution which gave birth to the concept of protecting human rights in the economic sector, which was initiated by the founding fathers, regarding Indonesian socialism. Hatta's idea was in line with Soekarno's thinking as "Indonesian-style socialism" which was adapted to Indonesian conditions. Qualitative research with normative juridical research type with secondary data by means of literature study. The conclusions of this study are 1) so far regulations have not provided much protection for human rights in the economic field, because they are against the principles of economic democracy in Article 33 of the Constitution 1945, so that the interests of citizens are marginalized. 2) regulations so far have more accommodated the principles adhered to by developed countries, the emergence of the era of liberalization, world trade without protection and without obstacles, will increase the level of trade competition among economic actors in Indonesia.
\end{abstract}

Keywords: Economic Rights; Human Rights Protection; Social justice;

\section{A. INTRODUCTION}

The big task of filling Indonesia's independence is a spirit that must be carried out by carrying out various activities and work programs while still living the spirit of revolution to achieve the country's goals. The revolution for the awakening of the Indonesian nation as a former colony and confined in the realm of feudalism for so long, had to struggle with two revolutions, namely the political revolution (national) and the socioeconomic revolution. The political revolution and the socio-economic revolution are in order to fight the new colonialism and new imperialism 
which is currently controlled by the great narratives of neocapitalism and neoliberalism. ${ }^{1}$

The main objective of the struggle for Indonesian independence was to liberate the nation from the exploitation of economic rights by the Dutch colonialists, so one of the agendas that was fought for was to make a total correction of the Dutch East Indies colonial economic structure, to become an Indonesian economic structure marked by the rise of the people as masters in the country themselves. ${ }^{2}$ Revrison Baswir, in a book entitled Manifesto of People's Economy by quoting Bung Karno's opinion, the colonial character of Indonesia's economy has at least three characteristics as follows; first, the Indonesian economy is only positioned as a supplier of raw materials to industrialized countries. Second, the Indonesian economy tends to be used as a market for finished goods made by advanced industrial countries. Third, the Indonesian economy is used as a place to rotate the excess capital found in advanced industrial countries. Revrison further quoted Hatta's opinion that the socio-economic structure of the Dutch East Indies was marked by the division of Indonesian society into three strata, first, the prosperous upper class inhabited by Europeans. Second, the middle layer that controlled trade was inhabited by foreign easterners. Third, the poor lower classes are inhabited by natives or indigenous Indonesians. ${ }^{3}$

Human rights have a strong place in the Indonesian constitution. The Indonesian people uphold the Pancasila state system of the 1945 Proclamation Constitution as the actualization of the philosophy of life (welt sanchanung) mandated by PPKI which contains teachings about the potential and dignity of human personality which is awarded with noble dignity as outlined in human rights teachings. ${ }^{4}$ Human Rights are the basic rights and freedoms to which all human beings are entitled, like civil and political rights, the right to life and liberty, freedom of thought and speech/expression, equality before the law, social, cultural and economic rights, the right to food, the right to work, and the right to education. ${ }^{5}$

The Constitution 1945 as the highest source of law contains provisions on rights in the political field as well as rights in the economic field, so that the Constitution 1945 regulates provisions on political democracy as well as economic democracy. Entering the early period of reform, political democracy with the model of direct presidential election by the people made the presidential government system parallel to the market mechanism and refused to interfere with the needs of the citizens. ${ }^{6}$

1 Yudi Latif, 2013, Mengurai Jembatan Emas Dengan Jiwa Merdeka, Kompas on 20 August 2013

2 Revrison Baswir, 2009, Manifesto Ekonomi Kerakyatan, Pustaka Pelajar, Yogyakarta, page.68

3 Ibid.

4 Suroto, "Human Dignity and Dignity in the View of the State of Pancasila and the Constitution 1945 of the Republic of Indonesia", in the Journal of Legal Reform, Volume II No.3 September - December 2015, page.314

5 Saleh Raed Shatat, International Law Internations And Human Rights, Journal of Legal Reform, Volume VI April 2 - August 2019, page. 274

6 Aidul Fitriciada Azhari, 2010, The Constitution 1945 Sebagai Revolusi Gronwet, Jalasutra, Yogyakarta, Jalasutra, Yogyakarta, page.161 
Nonetheless, the market mechanism is a neutral area of various sociopolitical and economic interests, which will influence every presidential policy and presidential management pattern in running the government both in the political and socio-economic fields. ${ }^{7}$ After the amendment of the Constitution 1945, the development of political democracy and government in Article 4, Article 5, Article 6A, and Article $22 \mathrm{E}$ of the Constitution 1945 has shown a capitalist-liberalistic character. The term capitalist-liberalism in the contemporary political era has experienced a shift and development along with the transformation and modification in the capitalist economic system. Now capitalism is not just an economic order (organization), but has increasingly become a political, socio-cultural, even ideological order (organization). ${ }^{8}$

In its development the normative for economic democracy in Article 33 applies economic democracy which does not want "economic autocracy" because the essence of democracy is participation and emancipation. ${ }^{9}$ Likewise, the formulation of Article 34 of the Constitution 1945 for the realization of welfare and social justice. Muhammad Hatta has emphasized that Indonesia's economic democracy is based on collectivism that Hatta articulated in the highest normative constellation, namely the constitution. ${ }^{10}$ Article 33 paragraph (1) (2) (3) is still intact which has a more religious socialist character (although there are additional paragraphs (4) and paragraph (5)). The President as head of government has the responsibility to implement economic democracy by embodied in various regulations issued by the state.

In the context of realizing economic democracy, the president has a big responsibility to realize an economic system that is in line with the philosophical basis of the nation and the constitution as the basis for every government policy. In the reform era, the government made policies and expanded employment opportunities, including direct assistance policies, such as direct cash assistance (BLT), the Social Safety Net program (JPS), Pre-Employment Cards, Indonesian Health Cards, Smart Indonesia Cards and various needs of residents who are categorized to get this assistance. This government policy has been widely criticized for its nature and its success has not been measured despite the fact that these programs have run concurrently with the agreement contained in the MDG's which is expected in 2015 for Indonesia to be free from poverty. However, these achievements were increasingly felt along with the Covid-19 pandemic, which seized huge amounts of state budget funds. The poverty level of residents has increased in percentage, because many people who lose their jobs and livelihoods, which have an impact on the economy with low growth, will reduce the level of welfare and justice that is felt by the citizens.

7 Ibid.

8 Edy Suandi Hamid, 2005, Ekonomi Indonesia dari Sentralisasi ke Desentralisasi, UII Press. Yogyakarta, page.13

9 Anwar Abbas, 2010, Bung Hatta dan Ekonomi Islam, Kompas, Jakarta, page.8-9 10 Ibid. 
Research conducted by Azwar Iskandar and Achmat Subekan concluded that the economic growth and political stability Granger cause democracy. It is the economic performance that influences democracy and not the reverse. In short-run, there is neutrality causation between democracy and growth, democracy and political stability, growth and political stability. These results suggest that economic growth through strong institutions is a precondition for democratization. ${ }^{11}$

Many people strongly believe that rising the challenge of sustainable development can help the country go forward in a better direction. One of the best approaches for promoting the sustainable development of Indonesia can be viewed from the perspective of human rights protection of the people. Basically, sustainable development encompasses three pillars based on environmental, economic, and social values that are interdependent and that mutually reinforce human rights. ${ }^{12}$

Human rights are defined as basic rights or basic rights. Human rights are often referred to as natural rights, basic human rights and natural rights. Kuncoro Purbopranoto defines human rights as rights owned by humans according to their nature, which cannot be separated from their dignity and are therefore sacred. Human rights in the view of Islam, There are basic rights inherent in humans, by al-Syatibi in al-Munafaqot, namely basic rights regarding religion (din), soul (nafs), honor ('irdh), descent (nasl) and property (mal). Ali Yafie added this concept to the concept of protecting the environment (hifz al-biah). By adding the basic rights to six, then it is called al-daruriyyatal-sitt. Individuals and the state must respect these human rights principles. In Act No. 39 of 1999 concerning Human Rights and Act No. 26 of 2000 concerning Human Rights Courts.

History of the birth of HAM experiencing conflicts, disputes and conflicts over economic, social and political resources. Finally, an agreement emerged to regulate society so as not to oppress, enslave and abuse individuals and community groups. The agreement is formulated in many forms in accordance with the context surrounding the joint rules, namely;

1. The Medina Charter in the 7th century, is the first written document in history that contains the basic principles of human rights. The Medina Charter in the original text is called al-shahifah. Its main content is, fostering unity and equality, security and expansion of territory, law and religious freedom, peace, sanctions and war.

2. Magna Charta of 1215 in England it was signed by King John Lackland with a number of nobles. Magna Charta contains restrictions on the absolute power of the king and can be accounted for in public.

3. Bill of Rights 1689 , which contains that humans are equal before the law (equality before law). This Charter gives birth to the principle of equality.

11 Azwar Iskandar and Achmat Subekan, Democracy and Growth Nexus in Indonesia, Journal of Development Economics: Study of Economic and Development Problems, Volume 20 No.2, 2019, page.208-221

12 Pan Mohamad Faiz, A Basic Foundation of Sustainable Development in Indonesia, The paper has been presented at Indonesian Students Scientific Meeting 2008, 13-15 May 2008 in Delft, The Netherlands and the Presenter awarded as the Best Oralist Presentation (Lecture) at the Conference), Human Rights Protection And Constitutional Review, 2008 
4. The French Declaration 1789, gave birth to the basis of The Rule of Law, which, among other things, contained a prohibition on arbitrary arrest and detention.

5. The 1948 Universal Declaration of Human Rights (UDHR) by the United Nations. This declaration is a moral manifesto, which has broad influence, inspires, becomes material for consideration and becomes educational material.

Experts divide the stages of human rights development into three generations, according to groupings according to areas of commonality: The first generation of human rights includes civil and political rights, in the language of negative rights: "freedom from"; The second generation of human rights includes rights in the economic, social and cultural fields. The rights of the second generation are formulated in positive terms: "right to", the third generation of human rights, including individual and collective rights, including the concept of the right to development. Jimly Asshiddiqie added that the fourth generation of human rights is related to the idealized balance between the state, market or entrepreneurs or business institutions and actors in civil society.

Jimly conceptualized the fourth generation of human rights as the concept of human rights viewed from a horizontal perspective. This is different from the three previous generations who saw human rights in the perspective of a vertical power relationship between the people and the rulers. Even though the state remains a responsible actor, the dominant group in society must also be seen as an actor that must guarantee the respect and protection of human rights.

The debate on the implementation of human rights in politics and in the socio-economic field can be caused by several factors; 1 ) There are different perspectives on human rights values, developed countries (West) adhere to the stance that human rights are universal. Therefore, standards, compliance and protection must be the same in all countries (Theory Natural Right). Third world countries adhere more to the standpoint of cultural relativism, that human rights must be seen in the cultural context of each country, because it causes differences in the implementation of human rights.

The issue of democracy and human rights (economic, social and cultural/eco-social) is an inseparable scientific study which has somewhat reduced the concept of state sovereignty by contextualizing the issue of security and individual welfare in life as citizens. Fulfillment of one of the economic, social and cultural rights, namely economic rights in Indonesia, has undergone developments and changes in the arrangement of norms, organizational structures, and private involvement and the role of civil society that have the opportunity, although not yet fully able to protect and protect every problem faced by citizens due to internal challenges and external countries are so strong, with the emergence of various international organizations that intervene in the interests of citizens, because of the impact of ongoing economic globalization. 
This writing is focused on the study of justice protection of human rights in the economic sector in the Constitution 1945. Based on what has been described, this research aims to analyze the protection of human rights in the economic field after the amendment of the Constitution 1945, as well as to analyze the challenges and obstacles in providing protection of human rights in the economic field in an effort to realize social justice in the Constitution 1945.

\section{B. RESEARCH METHODS}

The approach method used in scientific writing is a normative juridical research method, namely a process to find a rule of law, legal principles and legal doctrines to answer legal problems faced. ${ }^{13}$ Thus the normative legal research method is a scientific research procedure to find the truth based on the scientific logic of law from the normative side. The scientific logic that is consistent in normative legal research is built on the basis of scientific disciplines and the workings of normative legal science, namely the science of law whose object is law itself. ${ }^{14}$

The type of data used in this research is secondary data which includes primary legal materials and secondary legal materials, and tertiary legal materials obtained from books, literature, laws and regulations, papers and other data sources. Library material is the main support, while primary data is used as a complement and support for secondary data.

Secondary data collection is done by conducting an inventory of research materials using legal library materials related to this research, by means of tracing, grouping library materials conventionally by seeing, reading, listening, or using information technology (internet media). The legal materials are processed in stages of structuring, describing, and systematizing the legal materials.

\section{RESULTS AND DISCUSSION}

\section{The Human Rights Protection in the economic sector after the} amendment of Constitution 1945

The theory of democracy or people's sovereignty is the power of the people or civil society which becomes a source of energy and becomes an important subject for the government in formulating policies, especially those related to the basic needs of the people. The role of civil society is very important, as a political infrastructure that participates in the formation of laws, such as providing input, criticizing, supporting, and even suppressing state policies that are deemed unfair, useless and detrimental, strengthened by the emergence of local wisdom, leadership and figures. local customs, customs and religious values that are adhered to together, as a source of law formation,

13 Peter Mahmud Marzuki, 2005, Penelitian Hukum, Kencana, page.35 in Mukti Fajar and Yulianto Achmad, Dualisme Penelitian Hukum Normatif \& Empiris, Pustaka Pelajar, Yogyakarta, page. 34

14 Johhny Ibrahim, 2005, Teori \& Metodologi Penelitian Hukum Normatif, Bayumedia Publishing, Malang, page. 57 
especially laws that provide protection for just economic rights in accordance with the principle for the greatest prosperity of the people.

The constitutional guarantee of human rights has been formulated in the constitution. Basically, the constitution only regulates matters of a basic nature which can then be further regulated in regulations that are lower than the constitution. Even so, there are norms that are ordered to be further regulated from the constitution or the Constitution, so actually the regulation of these norms has a constitutional content as in practice it is often referred to as organic law, namely the order for the formation of laws from the constitution or the Constitution itself. The provisions are as contained in Article 28I Paragraph (5) The Constitution 1945 which reads "........... Then the implementation of human rights is guaranteed, regulated, and set forth in statutory regulations". This is very possible to make the development and development easier as well as the changing needs of the nation and state. Apart from these reasons, constitutional conventions are also possible to address the development and growth of the Constitution 1945, besides that the need to interpret the Constitution 1945 is important so that the constitution can live in the society of a nation. The authority to interpret the constitution was first owned by the legislators, namely the DPR and the President (see Article 20 Paragraph (2) of the Constitution 1945), after the formation of a law, the authority to further interpret is with the Constitutional Court as a constitutional guardian institution (the Guardian of the Constitution).

The Constitution 1945 prior to the amendment regulated only a few human rights, especially those related to the human rights of citizens which were more communal than individualist in nature. This can be traced in the debate regarding human rights material to be included in the constitution prepared by the founding fathers. There was a debate between Soekarno and Soepomo on the one hand who did not want human rights in the constitution because of their individualistic character, but Hatta and Yamin on the other hand considered human rights as important to be included in the constitution, because it would protect citizens from arbitrary actions by the authorities.

It can be understood that the formulation of HAW in the Constitution 1945 was strongly influenced by the development of the ideology of socialism which was very popular at the time after World War II, especially having a big influence on post-colonialism countries such as Indonesia. There has been a development from the concept of a formal/classical law state with a new, more dynamic concept of a legal state known as a welfare state, in which the state's duty is to actively participate in providing for the needs and protection of citizens to ensure their life.

According to Briggs, the role of the state in the concept of the welfare state is to modify various market forces, so that it is necessary to control and limit the operation of market forces to overcome negative elements that are not expected or due to the operation of these market 
forces. ${ }^{15}$ State intervention in economic activities remains within the balance of the interests of all parties in society, protecting the interests of producers and consumers, as well as protecting the interests of the state and public interests against corporate or private interests. ${ }^{16}$ In the development of a welfare state with a mixed economic system, according to Friedman, the state has four functions, the first being the state as a provider. Second, the state acts as a regulator. Third, direct intervention in the economy (entrepreneur), the fourth is the function of the state as a supervisor (umpire), maintaining order and justice and acting as a law enforcer. ${ }^{17}$

The Indonesian state is a country with the concept of a welfare state as affirmed in the state's objectives in the Preamble to the Constitution 1945, and further normalized in Article 33 and Article 34 of the Constitution 1945. The Constitution 1945 regulates provisions on political democracy as well as economic democracy. It is different from the tradition of writing constitutions in European and American countries whose services only contain constitutional material in the field of political rights. The tradition of constitutional writing in Indonesia, like socialist countries in Eastern Europe, is influenced by socialist ideology which is very popular in countries that were born after World War II such as Indonesia, even though the State of Indonesia is not a socialistcommunist country. ${ }^{18}$ Apart from these articles, there are several articles in the Constitution 1945 that provide protection of human rights in the economic field which are directly or indirectly related to economic matters. It can be shown related articles such as Article 23 concerning State Finances, and matters related to Article 27 Paragraph (2) concerning work and a decent living for humanity. Line IV of the Preamble of the Constitution 1945 contains the principles of Pancasila and state objectives which indirectly contain ideas about social welfare and the national economy. If detailed in the points and paragraphs in the Constitution 1945, there are 33 points of provisions which are directly or indirectly added to the fourth paragraph of the Preamble of the Constitution 1945, totaling 34 provisions in total relating to socialeconomic rights. ${ }^{19}$

The Constitution 1945 has formulated clear norms that the state has an important role in the field of economy and the welfare of its citizens, especially in the provision of jobs, as formulated in Article 27 Paragraph (2) of the Constitution 1945: "Every citizen has the right to work and a decent living for humanity." Article 28D Paragraph (2) of the Constitution 1945:" Every person has the right to work and to receive fair and proper compensation and treatment in a work relationship. In Article 31 paragraph (1) "every citizen has the right to education, the state

15 Johny Ibrahim, 2007, Hukum Persaingan Usaha. Filosofi, Teori, dan Implikasi Penerapannya di Indonesia, Bayu Media Publishing, Malang, page. 31

16 Ibid., page. 35

17 Ibid., page. 36

18 Jimly Asshiddiqie, 2010, Konstitusi Ekonomi, PT Kompas Media Nusantara, Jakarta, page. 8 19 Ibid., page. 247 
controls natural resources and production branches related to the livelihoods of many people, as well as in Article 34 Paragraph (1) of the Constitution 1945:" the poor and children neglected children are cared for by the state. Besides that, the private sector is also given a role in national economic activities. ${ }^{20}$ The provisions in the Constitution 1945 are an effort to protect human rights in the socio-economic field which is also emphasized in Article 28I Paragraph (4) that "Protection, advancement, enforcement and fulfillment of human rights are the responsibility of the state, especially the government". The formulation of these norms is an affirmation of the basics of state administration based on the principles of a democratic rule of law which can be interpreted as a manifestation of the fulfillment of Economic, Social and Cultural Rights as well as an indicator of achieving the goals of the Indonesian state, which was normatively carried out when the 2nd amendment to the Constitution 1945 human rights that have received attention and have been guaranteed in the Constitution 1945, as confirmed in Article 28I Paragraph (5) "To uphold and protect human rights in accordance with the principles of a democratic constitutional state.

The Constitution 1945 does not adequately regulate in more detail about human rights, so several laws and regulations were formed based on the order of the constitution, as a follow-up to normalizing civilpolitical rights and socio-economic rights in various laws known as organic laws. , or other ordinary laws such as Act No. 39 of 1999 concerning Human Rights, Act No. 26 of 2000 concerning Human Rights Courts, Act No. 29 of 1999 concerning Ratification of the Convention on the Elimination of All Forms of Discrimination. And several laws which are the result of the ratification of a number of international conventions and universal declarations on human rights as well as various other international legal instruments, such as: Act No. 11 of 2005 concerning Ratification of the International Covenant on Economic, Social, and Cultural Rights (ICESCR), and Act No. 12 of 2005 on International Covenant Civil and Political Rights (ICCPR).

Several laws related to the protection of rights in the economic sector as the implementation of the provisions in Article 33 Paragraph (5) "Further provisions regarding the implementation of this article are regulated in law", thus several laws were born such as Act No. 22 of 2001 concerning Oil and Gas, Act No. 20 of 2002 concerning Electricity, Act No. 19 of 2003 concerning BUMN, Act No. 7 of 2004 concerning Natural Resources, Act No. 25 of 2007 concerning Investment, Act No. 30 of 2009 concerning Electricity, Act No. 25 of 2007 concerning Investment, Act No. 40 of 2007 concerning Limited Liability Companies, Act No. 20 of 2008 concerning UMKM, Act No. 4 of 2009 concerning Mineral and Coal Mining. Apart from the provisions in the Constitution 1945, several of these laws act as a follow-up to the provisions of the

20 Edy Suandi Hamid, 2005, Ekonomi Indonesia dari Sentralisasi ke Desentralisasi, UII Press. Yogyakarta, page.10 
constitution as well as a form of follow-up to protect economic rights as an effort to reduce people's vulnerability to the factors that cause poverty and to increase their certainty against injustice and impoverishment.

\section{Challenges and obstacles to protecting human rights in the economic sector in the effort to achieve social justice in the Constitution 1945}

The role of civil society is very important because they are actually the owners of sovereignty in the country, and they are also the ones who have the greatest ability to exploit and enjoy natural resources. Therefore, their access to the use and management of natural resources must be given and widely opened by increasing the four (4) pillars of fulfilling economic rights, namely availability, increased access, conformity and adjustment.

In a certain period of time, the idea of people's sovereignty is often identified with democracy today, which tends not only to be seen as a political concept but includes economic democracy. It is increasingly realized that the guarantee of political rights alone is no longer sufficient to strengthen the position of the people in a country, especially in the realm of economic development in a society that tends not to side with the lower classes. It turns out that the guarantee of political democracy does not automatically create a democratic condition in the allocation of economic resources.

People's sovereignty is the antithesis of the idea of king's sovereignty, state sovereignty or other ideas of sovereignty that allow a few people to control the people at large (individualists) in politics (political democracy) and control the sources of livelihood in the economic field (economic democracy). The effort to reconcile the two democratic ideas received an adequate portion in the debates that developed among movement figures long before independence since the 1930s, among the concepts they thought about in preparation for an independent Indonesia.

In the field of law science, since a long time ago there have been three choices of attitude among experts regarding this matter. In the first view, individual values and interests are subordinated under collectivity. The second view, the values and interests of collectivity are subordinated to the individual. Meanwhile, the third view is to try to accommodate the claims of both values and interests in harmony. The first view, which subordinates individuality under collectivity, has been seen since ancient Greece and is seen also in the concept of theocracy in medieval Catholics and in the extreme socialism led by Marx. The second model was developed by the influential stoics in Rome to further develop thinking about individual supremacy. On progress, legal philosophy based on individualism emerged in the doctrine of absolute rights (inalienable right) which later became the basis of John Locke's legal and political theory, and Emmanuel Kahnt's moral and legal philosophy, 
Rousseou's social theory. The third view was led by Hegel who tried to combine the two previous views, which firmly adhered to the 'Organicist State' model known by Soepomo as kinship or integralistic theory.

What Hegel proposed as a combination of individualism and collectivism, is actually more of a collectivism option. This Hegelian philosophical system will continue to play an important role, especially in the present and future age of industrialization, which is growing rapidly in the context of the Individualism system. In line with Hegel, Bart Hessel claims to have succeeded in offering a combination of individualism versus collectivism through a concept called the 'relationistic concept of rechtsstaat and economic policy'. Jimly Asshiddiqie tries to take his enthusiasm or synthetic idealism, and from Bart Hessel he takes the lesson by still referring to the way of thinking of the Indonesian nation based on Pancasila in the life of the nation, society and state. ${ }^{21}$

Indicators of the position of individuals and collectivity in the developing dialectic between the extremes of individualism and collectivism are measured by looking at the dynamics of the role of the people and the state during the three periods of democracy. The greater the role of the people, the greater the respect for individuals, and this reflects the increasing respect for individuality the people in political democracy policies. Meanwhile in the economic sector, the dynamics of the role of the people are measured by the extent to which the legal products established during that period influenced the pattern of relations between the government and business entities. The greater the role of the state, the greater its interventionistic character as a welfare state, the greater will the degree of collectivism embraced in economic democratic policies.

The idea of people's sovereignty as the ideals of statehood has a long history, which has been discussed among movement figures, long before the draft of the Constitution 1945 was prepared. The idea of people's sovereignty being discussed was not the same as the sovereignty of the people that developed in West Europe at that time which was based on individualism and liberalism, but what Hatta was trying to develop was political democracy and economic democracy at the same time.

The emergence of the idea of people's sovereignty was strongly motivated by the spirit of anti-individualism, liberalism and capitalism. In general, all groups in the movement agree that the democratic nature referred to in democracy must be in accordance with Indonesian culture itself. The leaders of the movement idealized collectivism, which was seen as a creative combination of the various understandings they criticized, of individualism, liberalism, capitalism and imperialism on the one hand and communism and facism on the other.

21 Jimly Asshiddiqie, 1994, Gagasan Kedaulatan Rakyat Dalam Konstitusin Dan Pelaksanaannya Di Indonesia, PT Ichtiar Baru Van Hoeve, Jakarta, page.63 
The development of the idea of people's sovereignty undergoes an interpretation of meaning, due to several factors behind it, including the development of the philosophy behind it, ideological understanding, socio-politics as well as the development of national civilizations in the current era of globalization. Rejection of concepts can occur between individualism-capitalism and collectivism-socialism in building the state administration of a country, including Indonesia. The effort to combine the two understandings was a creative endeavor of the founding fathers, which may have been driven by the situation at that time.

The idea of people's sovereignty in the economic sector has been formulated explicitly in Article 33, with the aim of building people's economic strength. The first policy carried out by the government in the economic field was to first strengthen the power of economic control in the hands of the government. Actually, what needs to be considered is that the soul of the provisions of article 33 is cooperatives.

Government policies in the field of cooperatives until 1947 did not seem meaningful. In 1951 the government nationalized the companies inherited from the Netherlands, which eventually resulted in a dispute between the Indonesian government and the Dutch government at the International Court of Justice. All of these actions cannot be separated from their political background, so a common thread appears in which the role of the state is very large in controlling the conduct of business in Indonesia.

Basically, the policies during the Guided Democracy era and the Pancasila Democracy era, especially until the 80s looked similar. The government, within certain limits, can take protective measures, provide guidance, provide supervision and assistance to cooperatives to carry out their functions. Likewise, legal policies regarding cooperative issues during the Pancasila Democracy period were still very limited, not comparable to policies that were mostly established to accommodate the interests of the private sector companies.

There is a tendency that occurred in the three periods of the Indonesian democracy, namely regarding the pattern of interpretation or explanation of the basic ideas contained in the Constitution. The liberal democracy era, which played an important role in interpreting and describing the people's sovereignty in the constitution was the parliament and the President. During the guided democracy era, the dominant power to dictate operational concepts in the context of the elaboration of people's sovereignty rests in the hands of the President, both in the economic and political fields. It seems that a large-scale individualization and capitalization process took place in the national economic trade and finance sector, namely the issuance of a deregulation policy package, and this debureaucracy actually gave an opportunity for capitalist economic strength.

Cooperative development has not been designed as the pillar of the national economy. The condition of the cooperative is still far behind other business groups, such as State-Owned Enterprises (BUMN) and 
individual companies in the form of conglomerates. The development of cooperatives has changed in character and character, as has changes in the level of regulations or changes in the economic-political orientation of a regime. No less important than the development of cooperatives, namely the existence of institutional intervention into cooperative organizations, such as the structure of the organization held by certain people who have not guaranteed a professional level in their field.

Article 33 paragraph (4) of the Constitution 1945 will actually have the same meaning if the norms contained in the Explanation of the Constitution 1945 are included in articles, such as "building a cooperative company", but the normative formulation is not included in additional articles, considering that The MPR agreement in 1999 regarding normative matters stated in the explanation will be included in the articles of the Constitution 1945. Even the explanation of the Constitution 1945 was abolished, so that there is no constitutional basis for the role of cooperatives and restrictions on private companies in the Indonesian national economic system. ${ }^{22}$

This shows that there has actually been a rejection of the content of Article 33 of the Constitution 1945, even though it has retained the original Article 33 of the Constitution 1945 but has rejected the normative formula in the Elucidation of the Constitution $1945 .^{23}$

The era of world trade liberalization followed by the emergence of legal globalization that applies throughout the world will further strengthen the New Lex Mercatoria (NLM) with the spirit of unifying international trade law which is often considered a law capable of entering space and time to bridge ideological differences, differences in political culture and the economic systems of various countries. The existence of the NML can threaten the sovereignty in the formation of law, especially in the economic field. Even in the Asia Pacific region, APEC (Asia Pacific Corporation) and AFTA (ASEAN Free Trade Association) have been formed as a form of economic cooperation that leads to a common market. In addition, there is a form of trilateral cooperation around the economic growth triangle area, namely Singapore-Johor-Riau, and Malaysia-Thailand-Indonesia. ${ }^{24}$ Currently, this sovereignty is decreasing, especially the formation of laws such as trade, investment services, intellectual property rights and other provisions as agreed in GATT-PU. ${ }^{25}$

Various legal products in the economic sector as a means of running the government experience the same problems as in the early reform era during the era of Megawati Sukarnoputri's leadership. During the 2004-2009 government period, many laws were requested for

22 Aidul Titriziada Azhari, 2011, The Constitution 1945 Sebagai Revolutiegrondwet, Jalasutra, Yogyakarta, page. 165

23 Ibid.

24 Absori, 2013, Politik Hukum Menuju Hukum Progresif, Muhammadiyah University Press, Surakarta, page.39

25 Adi Sulistiyono, 2009 Negara Hukum, Kekuasaan, Konsep, Dan Paradigma Moral, Sebelas Maret University Perss, Surakarta, page.28 
judicial review to the Constitutional Court such as Act No. 19 of 2003 on BUMN, Act No. 25 of 2007 concerning Investment, Act No. 40 of 2007 regarding Limited Liability Companies, Act No. 30 of 2009 concerning Electricity and Act No. 4 of 2009 concerning Mineral and Coal Mining, which is allegedly inconsistent and coherent with Article 33 of the Constitution 1945.

The phenomenon of the number of judicial reviews at the Constitutional Court is also related to the process of legal formation, especially in the economic sector, which is associated with the election system for political positions within the state institutional structure in the Constitution 1945 which is full of investors' interests for their business interests. Likewise, the external factors can be seen from the legal politics which is influenced by economic globalization which has an impact on legal globalization, as well as a paradigm shift in the field of economic law. Independence and sovereignty in the formation of laws are lost when economic globalization and global economic pressures have an impact on the making of legislation, especially in the fields of trade, services, investment, intellectual property rights and other provisions as regulated in GATT-PU. ${ }^{26}$ Global economic pressure will reduce the State's authority and ability to protect the socio-economic interests of its citizens. This will worsen the achievement of various development programs scheduled in the RPJP, RPJM, and RKP, which results in not protecting economic rights and achieving social justice even further.

The provisions in the Constitution 1945 are used as a formal reference to show that the policy is seen to be in line with Article 33 and Article 34 of the Constitution 1945. However, the reference to this article is only used as a basis for the preamble of "weighing" but is not elaborated in the contents of the Law (only proforma or formality in nature). Likewise, the Constitution 1945 contains basic policies in the economic sector, which are only of nominal value or semantic in nature when the basic policies in their implementation are not used as references in the formation of laws in the economic sector.

Article 33 paragraph (4) which emphasizes economic democracy has not been elaborated properly because BUMN issues are not taken seriously and become agents of economic development, as well as planning to strengthen cooperative business entities so that they become the pillars of the people's economy has not been implemented properly. Currently, the agenda in the National Medium Term Development Plan (RPJM) is under influence and pressure from global political and economic interests that dominate the formation of laws and regulations in the economic sector. Globalization in the economic sector is based on free competition and free markets which have resulted in increasingly sharp inequality which is felt especially for people who are economically weak and marginalized. This situation will become increasingly clear that economic globalization will have a direct impact on global economic 
regulation. The global economy will foster capitalism and individualism principles that are contrary to the principles of togetherness and kinship that exist in Article 33 of the Constitution 1945, and result in weakening the protection of the socio-economic rights of citizens.

\section{CONCLUSION}

The legal politics of human rights protection in the economic sector after the amendment of the Constitution 1945 has clearly formulated that the state has an important role in the economic sector and the welfare of its citizens, especially in the provision of jobs, as formulated in Article 27 Paragraph (2) of the Constitution 1945: "Every citizen has the right to work and a decent living for humanity ", Article 28D Paragraph (2) of the Constitution 1945:" Everyone has the right to work and to receive fair and proper compensation and treatment in a working relationship. In Article 31 paragraph (1) "every citizen has the right to education, the state controls natural resources and production branches which are related to the livelihood of many people, as well as in Article 34 Paragraph (1) of the Constitution 1945: "The poor and neglected children are cared for by the state" besides that the private sector is also given a role in national economic activities. The provisions in the Constitution 1945 are an effort to protect human rights in the socio-economic field which is also emphasized in Article 28I Paragraph (4) that "Protection, advancement, enforcement and fulfillment of human rights are the responsibility of the state, especially the government". The formulation of these norms is an affirmation of the principles of state administration based on the principles of a democratic rule of law which can be interpreted as a manifestation of the fulfillment of ESC rights as well as an indicator of achieving the goals of the Indonesian state as agreed in the Constitution 1945 has been guaranteed in the Constitution 1945.

The challenges and obstacles in protecting human rights in the economic sector are felt real when independence and sovereignty in the formation of laws is lost when economic globalization and global economic pressures have an impact on the formation of laws and regulations, especially in the fields of trade, services, investment, intellectual property rights and regulated provisions in GATT-PU. Global economic pressures will reduce the state's authority and ability to protect the socio-economic interests of its citizens through various regulations that do not protect the rights of citizens. In developing countries such as Indonesia, the struggle and recognition and protection of human rights, especially in the economic field in an effort to realize human rights in the economic field, are strongly driven by the spirit of anti-individualism, liberalism and capitalism. In general, all groups in the independence movement agree that the populist character referred to in economic democracy must be in accordance with Indonesian culture and national identity. The leaders of the movement idealized collectivism, which was seen as a creative combination of the various understandings they criticized, of individualism, liberalism, capitalism and imperialism on the one hand and communism and facism on the other. 
Efforts to realize the protection of human rights in the economic sector include the establishment of laws and regulations by state institutions and officials who have the authority to make written regulations by reaffirming the spirit to implement economic democracy based on Pancasila values and the provisions of Article 33 of the Constitution 1945.

Books :

\section{BLIBIOGRAPHY}

Absori, 2013, Politik Hukum Menuju Hukum Progresif, Muhammadiyah University Press, Surakarta;

Adi Sulistiyono, 2009, Negara Hukum, Kekuasaan, Konsep, Dan Paradigma Moral, Sebelas Maret University Perss, Surakarta;

Aidul Fitriciada Azhari, 2010, The Constitution 1945 Sebagai Revolusi Gronwet, Jalasutra, Yogyakarta;

Anwar Abbas, 2010, Bung Hatta dan Ekonomi Islam, Kompas, Jakarta;

Edy Suandi Hamid, 2005, Ekonomi Indonesia dari Sentralisasi ke Desentralisasi, UII Press. Yogyakarta;

Jimly Asshiddiqie, 2006, Pengantar Ilmu Hukum Tata Negara Volume 1, Constitution Press, Jakarta; Jakarta; 2010, Konstitusi Ekonomi, PT Kompas Media Nusantara,

Johhny Ibrahim, 2005, Teori \& Metodologi Penelitian Hukum Normatif, Bayumedia Publishing, Malang; 2007, Hukum Persaingan Usaha. Filosofi, Teori, dan Implikasi Penerapannya di Indonesia, Bayu Media Publishing, Malang;

Muhammad Syarifudin, 2009, Menggagas Hukum Humanis-Komersial (Upaya Perlindungan Hukum Hak Masyarakat Kurang Mampu Atas Pelayanan Kesehatan Rumah Sakit Swasta Berbadan Hukum Perseroan Terbatas), Bayumedia, Malang;

Peter Mahmud Marzuki, 2005, Penelitian Hukum, Kencana in Mukti Fajar and Yulianto Achmad, Dualisme Penelitian Hukum Normatif \& Empiris, Pustaka Pelajar, Yogyakarta;

Revrison Baswir, 2009, Manifesto Ekonomi Kerakyatan, Pustaka Pelajar, Yogyakarta;

\section{Journals :}

Azwar Iskandar and Achmat Subekan, Democracy and Growth Nexus in Indonesia, Journal of Development Economics: Study of Economic and Development Problems, Volume 20 No. 22, 2019;

Pan Mohamad Faiz, $A$ Basic Foundation of Sustainable Development in Indonesia, The paper has been presented at Indonesian Students 
Scientific Meeting 2008, 13-15 May 2008 in Delft, The Netherlands and the Presenter awarded as the Best Oralist Presentation (Lecture) at the Conference), Human Rights Protection And Constitutional Review, 2008;

Saleh Raed Shatat, International Law Internations And Human Rights, Journal of Legal Reform, Volume VI April No.2 - August 2019;

Suroto, Human Dignity and Dignity in the View of the State of Pancasila and the Constitution 1945 of the Republic of Indonesia, Journal of Legal Reform, Volume II No.3 September - December 2015;

\section{Regulations :}

The Constitution 1945 of the Republic of Indonesia and its amendments;

MPR Decree Number XVI/MPR/1998 concerning Political Economy in the Context of Economic Democracy;

MPR Decree Number IV/MPR/1999 concerning State Policy Guidelines;

Act No. 1 of 1957 concerning Foreign Investment (LNRI No. 1, 1967; TLN No. 2818);

Act No. 25 of 1992 concerning Cooperatives;

Act No. 8 of 1995 concerning Capital Market;

Act No. 25 of 2000 concerning the National Development Planning System;

Act No. 22 of 2001 regarding Oil and Natural Gas;

Act No. 20 of 2002 concerning Electricity;

Act No. 19 of 2003 concerning State-Owned Enterprises (BUMN);

Act No. 25 of 2007 concerning Investment. 